$12-24-2020$

\title{
Analytic Jurisprudence in Time
}

Dan Priel

Osgoode Hall Law School of York University, dpriel@osgoode.yorku.ca

\section{Source Publication:}

Bustamante, Thomas da Rosa de, and Thiago Lopes Decat. Philosophy of Law as an Integral Part of Philosophy : Essays on the Jurisprudence of Gerald J. Postema . First edition., Hart Publishing, an imprint of Bloomsbury Publishing, 2020, doi:10.5040/9781509933914.

Follow this and additional works at: https://digitalcommons.osgoode.yorku.ca/scholarly_works

Part of the Jurisprudence Commons

\section{Repository Citation}

Priel, Dan, "Analytic Jurisprudence in Time" (2020). Articles \& Book Chapters. 2860.

https://digitalcommons.osgoode.yorku.ca/scholarly_works/2860

This Book Chapter is brought to you for free and open access by the Faculty Scholarship at Osgoode Digital Commons. It has been accepted for inclusion in Articles \& Book Chapters by an authorized administrator of Osgoode Digital Commons. 


\title{
10 \\ Analytic Jurisprudence in Time
}

\author{
DAN PRIEL
}

\section{INTRODUCTION}

Friedrich Nietzsche had this to say about philosophers:

You ask me which of the philosophers' traits are really idiosyncrasies? For example, their lack of historical sense, their hatred of the very idea of becoming, their Egypticism. They think that they show their respect for a subject when they de-historicize it, sub specie aeterni - when they turn it into a mummy. All that philosophers have handled for thousands of years have been concept-mummies; nothing real escaped their grasp alive. When these honorable idolators of concepts worship something, they kill it and stuff it; they threaten the life of everything they worship. Death, change, old age, as well as procreation and growth, and to their minds objections - even refutations. Whatever has being does not become; whatever becomes does not have being. ${ }^{1}$

Rather than take offence, many philosophers these days will consider Nietzsche's words a compliment. Bernard Williams reported on a fellow philosopher who had told him that 'the history of philosophy is no more part of philosophy than the history of science is part of science'. ${ }^{2}$ In a similar vein, Tom Sorell observed that 'the techniques and predilections of analytic philosophy are not only unhistorical but anti-historical'. ${ }^{3}$ The majority of Anglophone legal philosophers

\footnotetext{
${ }^{1}$ F Nietzsche, 'Twilight of the Idols: Or, How One Philosophizes with a Hammer' in The Portable Nietzsche, ed and tr Walter Kaufmann (first pub 1888, Viking 1954) 463, 479-80 (III, \$1). Incidentally, one of Nietzsche's illustrations of how concepts 'become' rather than 'are' dealt with a legal example: punishment. See F Nietzsche, On the Genealogy of Morals, tr D Smith (first pub 1887, Oxford University Press 1996) 44-53.

${ }^{2}$ B Williams, 'Philosophy as a Humanistic Discipline' (2000) 75 Philosophy 477, 486.

${ }^{3}$ T Sorell, 'Introduction' in T Sorell and GAJ Rogers (eds), Analytic Philosophy and History of Philosophy (Oxford University Press 2005) 1, 1. Both Williams and Sorell challenged this view. For a moderate endorsement of this ahistoricist conception of philosophy, see T Williamson, Doing Philosophy: From Common Curiosity and Logical Reasoning (Oxford University Press 2019) 105. Interestingly, Williamson calls this philosophical practice 'Oxford-style' (ibid 100). This approach fits nicely within what I consider elsewhere the dominant approach to philosophy at Oxford, which has had much influence on legal philosophy in the English speaking world. See D Priel, 'EvidenceBased Jurisprudence: An Essay for Oxford' [2019] 2 Analisi e Diritto 87.
} 
are no different. HLA Hart once wrote that '[a]nalytical and historical inquiries provide answers to different questions not different answers to the same questions'. ${ }^{4}$ Sixty years later Andrei Marmor expressed a similar sentiment when he wrote, ' $[\mathrm{t}]$ he motivation for claiming that $P$ is one thing, and the truth of $P$ is another. The former is the business of intellectual historians. Philosophy should be interested in truth. ${ }^{5}$

Ignoring history, you might say, is exactly what gives philosophy its raison d'être, it is precisely what distinguishes the philosophical study of social institutions from all others. Indeed, to the extent that legal philosophers should seek to identify the features that all laws necessarily have, ${ }^{6}$ history looks like a distraction. This is not meant to denigrate either method or form of inquiry, just to say that they are different and broadly independent of each other. Legal theorists and legal historians (including historians of jurisprudence) should therefore go on pursuing their valuable interests without caring much about the others' work. For quite some time, this has been, I think, the dominant view. $^{7}$

But can philosophers of law really insulate their inquiries from law's history, from the temporal element of law? And should they? Is there any basis for thinking that the philosophy of law may be different on this score from some other areas of philosophy? Despite the dominance of the ahistorical approach, several legal philosophers have been critical of the almost complete separation between the two inquiries. ${ }^{8}$ Few have thought about these questions harder than Gerald Postema, who explored this question in different ways both in his work

\footnotetext{
${ }^{4}$ HLA Hart, 'Introduction' in J Austin, The Province of Jurisprudence Determined, ed HLA Hart (first pub 1832, Weidenfeld \& Nicolson 1954) vii, xv.

${ }^{5}$ A Marmor, Philosophy of Law (Princeton University Press 2011) 118.

${ }^{6}$ A view defended, among others, in J Raz, The Authority of Law: Essays on Law and Morality (2nd edn, Oxford University Press 2009) 104; L Green, 'Jurisprudence for Foxes' (2012) 3 Transnational Legal Theory 150, 157-58.

${ }^{7}$ See G Samuel, 'Science, Law and History: Historical Jurisprudence and Modern Legal Theory' (1990) 41 Northern Ireland Legal Quarterly 1, 2 ('The modern view is, on the whole, that history itself cannot provide a philosophy of law'); AT Kronman, 'Precedent and Tradition' (1990) 99 Yale Law Journal 1029, 1058 ('Professional philosophy ... grants the past no more authority than chemistry and physics do, and like them insists that its own accomplishments be judged solely in accordance to the timeless criterion of truth.').

${ }^{8}$ Jeremy Waldron, for example, reported that some think the ahistoricity of jurisprudence is 'a good thing: it means we can study the problems of legal philosophy directly, undistracted by a purely antiquarian interest in the history of ideas'. But Waldron criticised such views as leading to discussions that are 'flat and repetitive'. See J Waldron, 'Legal and Political Philosophy' in JL Coleman and SJ Shapiro (eds), The Oxford Handbook of Jurisprudence and Philosophy of Law (Oxford University Press 2002) 352, 381 (hereinafter Oxford Handbook). Outside the world of analytic jurisprudence, this criticism has been more common. See, eg, B Edgeworth, 'Legal Positivism and the Philosophy of Language: A Critique of HLA Hart's Descriptive Sociology' (1986) 6 Legal Studies 115, 125; MJ Horwitz, 'Why Is Anglo-American Jurisprudence Unhistorical?' (1997) 17 Oxford Journal of Legal Studies 551, 564-65. For a recent attempt by a socio-legal scholar to revive historical jurisprudence, see BZ Tamanaha, A Realistic Theory of Law (Cambridge University Press 2017) chs $1,4$.
} 
on general jurisprudence and in his work explicating the philosophy of the common law and that of the common law's greatest hater, Jeremy Bentham. ${ }^{9}$

I aim to explore some of these questions in this chapter, partly by engaging in Postema's work on this topic. But the chapter pays tribute to his work in another way. Though he sees himself as a philosopher and not a historian of ideas, Postema's work shows more sensitivity than is common in most contemporary legal philosophy to the historically-situated nature of philosophical work. What he did in relation to Matthew Hale and Jeremy Bentham, I aspire to do in this chapter with respect to aspects of twentieth-century jurisprudence. Because contemporary legal philosophy is written in a self-consciously ahistorical style, it invites an ahistorical assessment of its products. This chapter seeks to contribute to a better historical understanding of analytic jurisprudence itself by tying its emergence to a particular intellectual climate. Finally, this chapter also turns to the history of philosophy to trace the origins of some popular jurisprudential ideas. Just as Postema has shown that, contrary to prevailing belief among legal philosophers, the idea of law as command was not invented by Thomas Hobbes, ${ }^{10}$ I want to show that some well-known jurisprudential ideas have a long history outside of jurisprudence. To that end, I show (with the aid of what may be an unseemly large number of block quotations) just how similar are some of the views expressed within analytic jurisprudence to ideas we encounter, sometimes centuries earlier, in other areas of philosophy. This serves yet another goal, one reflected in the title of this volume, that of seeing the connections between legal philosophy and some of the central questions in other areas of philosophy. ${ }^{11}$

\section{JURISPRUDENCE AS A PROGRESSIVE SCIENCE}

To some of Hart's admirers, his most important contribution to jurisprudence has not been any of his central substantive ideas but the way he oriented jurisprudence towards analytic philosophy and (for lack of a better term) its ethos. ${ }^{12}$

\footnotetext{
${ }^{9}$ I express my appreciation for Postema's contribution to the study of Bentham in D Priel, 'Bentham's Public Utilitarianism and Its Jurisprudential Significance' (forthcoming).

${ }^{10}$ See GJ Postema, 'Law as Command: The Model of Command in Modern Jurisprudence' (2001) 11 Philosophical Issues 470, 470-75.

${ }^{11}$ Showing that serves an additional purpose. I have complained elsewhere about the isolationism of contemporary legal philosophy. See Priel (n 3) 98-109. One way of demonstrating this isolation is by showing how unaware are legal philosophers of the origins of jurisprudential ideas they treat as path breaking.

${ }^{12}$ See, eg, LJ Green and B Leiter, Letter to the Editor, 'H.L.A. Hart and "The Concept of Law"' Times Literary Supplement (London, 11 March 2005) 15, 15 ("[Hart] ... transformed the discipline of jurisprudence. What had been a dilettantish pastime for law teachers and retired judges, an undisciplined jumble of history, speculative sociology, legal doctrine and party politics, became technical and rigorous branch of philosophy.'); J Murphy and JL Coleman, Philosophy of Law: An Introduction (rev edn, Westview 1990) 26-27.
} 
Hilary Putnam captured well that ethos, especially around the middle of the twentieth century, the time Hart was making his most influential contributions:

(1) Analytical philosophy is nonideological, which means above all that it is nonpolitical and nonmoralizing. (2) Analytical philosophy consists of piecemeal problem solving. ... (3) Analytical philosophy for a long time regarded value theory as secondclass philosophy, and a concern with literature, the arts, culture, and the history of culture as at best optional for an analytical philosopher (although this has begun to change as a result of the publication of John Rawls's A Theory of Justice ...). ${ }^{13}$

There can be little doubt that at least in the English-speaking world, it was Hart's work more than anyone else's that gave the impetus for aligning jurisprudence with developments in twentieth-century philosophy, making jurisprudence almost synonymous with legal philosophy. And indeed, the central features of analytic philosophy that Putnam identified are also an excellent summary of Hart's conception of jurisprudence: Hart stated that his inquiry is 'general and descriptive', ${ }^{14}$ which he took to be morally and politically neutral. Hart also embraced the idea of piecemeal progress: In an interview he gave late in his life, he was explicit that analytic philosophy 'is suspicious of grand theory if it comes along too soon and obscures valuable distinctions', ${ }^{15}$ and that he himself 'had no part in that sort of thing'. ${ }^{16}$ Putnam's third point is also prominent in Hart's work. His most important work appeared in the two decades prior to the publication of A Theory of Justice and it generally avoided questions of value. Hart later stated that he thought that analysing law and politics using 'so far as possible a morally neutral vocabulary ... [to be] the sane and healthy centre' of legal positivism. ${ }^{17}$

It may be a measure of Hart's enormous impact on the field that Putnam's three characteristics remain dominant in contemporary jurisprudence, often presupposed rather than defended. So understood, legal philosophy (like much of philosophy more generally) is in one important sense modelled after the natural sciences: in terms of its aims, it seeks to provide an accurate description of what law is; in terms of its methodological aspirations, it is to be as value neutral as good science is. ${ }^{18}$ Scientific inquiry, specifically about the nature of chemical substances, provides a good analogy for this approach to jurisprudence.

\footnotetext{
${ }^{13}$ H Putnam, 'Convention: A Theme in Philosophy' (1981) 13 New Literary History 1, 10-11.

${ }^{14}$ See HLA Hart, The Concept of Law (3rd edn, Oxford University Press 2012) 239.

${ }^{15}$ See 'Hart Interviewed: HLA Hart in Conversation with David Sugarman' (2005) 32 Journal of Law and Society 267, 290.

16 ibid 292; contra L Green, 'Introduction' in Hart (n 14) xv, xlvii.

${ }^{17}$ See HLA Hart, Essays on Bentham: Studies in Jurisprudence and Political Theory (Clarendon Press 1982) 28; D Priel, 'The Place of Legitimacy in Legal Theory' (2011) 57 McGill Law Journal 1, $14-18$.

${ }^{18}$ It is important to stress that jurisprudence is modelled after science only in these specific senses. In other senses, much contemporary jurisprudence remains staunchly resistant to the influence of the natural sciences. See D Priel, 'Jurisprudence Between Science and the Humanities' (2012) 4 Washington University Jurisprudence Review 269, 301-07. The present chapter aims to make sharper the tension within this ambivalent attitude toward science.
} 
Gold can be shaped in different ways (coins, rings, bullion); the cultural significance of gold has also changed throughout history. But underneath these differences there remains the essence of gold, unchanging throughout history, and completely independent of human knowledge of it.

The progressive-science model of jurisprudence adopts the same view with respect to law. Underneath the superficial differences that distinguish one law or legal system from others, there is a fundamental, unchanging core; and this unchanging core is unaffected by misconceptions, no matter how commonly held. If there is, for example, a necessary connection between law and morality, that remains the case even if all humans think otherwise. By the same token, biographical data on Hobbes or Bentham, or contextual information about debates they had with their contemporaries, bear as much relevance to jurisprudence as the question whether an apple fell on Newton's head or whether Galileo dropped two cannon balls from a tower in Pisa has to the truth of gravity.

This approach has a similar response to legal change. It is not that laws, or even that prevailing ideas about law, do not change. Rather, the thought is that underneath these changes, there is a single, unchanging nature that law in all times and places possesses, one that exists, as it were, outside of time and space. On this view, the most significant sense in which time figures in jurisprudential inquiry is that different scholars work to discover the nature of one object by exploring some questions pursued by their predecessors, on whose answers they hope to build. Thus, John Austin and Jeremy Bentham pointed out errors in then-prevailing natural law theories, Hart improved on Austin and Bentham by correcting their errors and so on. Progress in this kind of inquiry is attained by adopting a problem-solving, knowledge-accumulating inquiry, one in which the bigger picture about law is generated out of solutions to smaller questions such as what an obligation, a right or a duty are.

This model of inquiry explains why legal philosophers are generally uninterested in the history of law: They focus on the timeless, whereas historians are interested in change. It also explain legal philosophers' lack of interest in the history of jurisprudence. No one denies the genius of Newton or Darwin or their epoch-making contributions to physics and biology, but these days scientists do not turn to them for answers to open questions in physics or biology, because physical and biological knowledge has progressed far beyond them. Their insights have been accepted and added to the store of knowledge, built upon, and in important respects also superseded and corrected. Similarly, on the model of philosophy as a progressive science, philosophers today know more and have advanced far beyond Hobbes, Hume, Bentham or Kant, so there is relatively little to learn from them that could assist in addressing contemporary debates. ${ }^{19}$

\footnotetext{
${ }^{19}$ See LD d'Almeida, 'Book Review' (2015) 78 Modern Law Review 699, 707 ('What matters is whether there is philosophical progress to be made by working on [the ideas of earlier thinkers] ... [Legal philosophers] are concerned with the same thing Raz is concerned with. They are concerned with getting things right.'). See also text to n 5 .
} 
Thus, in the course of defending such a conception of legal philosophy, John Gardner rhetorically asked, 'Why tackle today's problems, the possibly transient concerns of the early twenty-first century, at the expense of the timeless problems that were also of interest to Plato, Confucius, and Maimonides?'20 But if one wonders why the writings of Confucius, Maimonides (and even Plato) are so rarely discussed in contemporary jurisprudence, the progressivescience approach has a ready response. On the 'timeless questions' that legal philosophy deals with, there has been so much advance since the days of ancient philosophers that there is not much to gain from reading them. Looking at their work may serve a pedagogical purpose, it may help in avoiding some pitfalls, ${ }^{21}$ but not much else.

To be sure, one still finds occasional references to historical figures, but there is little interest in reading them in the context of the intellectual debates of their day. To the extent that we should care about what they wrote, it is for their ability to contribute to contemporary debates. ${ }^{22}$ As a result, to the extent that we encounter jurisprudential history in most contemporary work, it is a simplistic history in which whole centuries are reduced to a few sentences. ${ }^{23}$

To proponents of this view, the only minor concession to history seems to be the acknowledgement that the practice of jurisprudence (and philosophy more generally) is the product of changes in the interests of their audiences. This means some questions will be explored in certain times but not in others, and may make what counts as a good explanation of law relative to a time and a place, but 'there is nothing in the relativity of good explanations to their public to threaten the non-relativity of truth'. ${ }^{24}$

\footnotetext{
${ }^{20} \mathrm{~J}$ Gardner, Law as a Leap of Faith: Essays on Law in General (Oxford University Press 2012) 297 , fn 75 .

${ }^{21}$ It is common to find contemporary scholars discussing the works of John Austin in order to learn from his mistakes. See SJ Shapiro, Legality (Harvard University Press 2011) 59 (despite its many errors 'Austin's theory of law presents us with a tremendous learning opportunity'). Of course, Hart used Austin's ideas for a similar purpose, and he was not even the first to do so. See HF Jolowicz, Lectures on Jurisprudence, ed JA Jolowicz (Cambridge University Press 1963) 15 (based on lectures delivered between 1924 and 1948) ('[Austin's] theories represent a very definite and clear conception which, in outline at least, is easy to grasp ... Austin's doctrine forms a very good target - we must set it up and see it clearly in order to throw bricks at it').

${ }^{22}$ Bernard Williams (n 2) 478, described the view as asking us 'to read something by Plato "as though it had come out in Mind last month"'. Williams criticised this view, which he associated with the 'heyday of confidence in what has been called the "analytic history of philosophy"'.

${ }^{23}$ cf H Kelsen, 'The Pure Theory of Law: Its Methods and Fundamental Concepts' (1934) 50 Law Quarterly Review 474, 483-84 (a brief narrative of jurisprudential progress, in which natural law was replaced with positivist theory, then refined by Kelsen's pure theory of law).

${ }^{24} \mathrm{~J}$ Raz, Between Authority and Interpretation (Oxford University Press 2009) 57-58; see also J Dickson, 'The Central Questions of Legal Philosophy' (2003) 56 Current Legal Problems 63, 85-90. Like Raz, Dickson insists that this view does not challenge the enterprise 'understanding the nature of law by identifying and explaining its essential [ie timeless] properties': ibid 90.
} 


\section{JURISPRUDENCE AS INTERPRETATION OF A SOCIAL PRACTICE}

Not everyone agrees with the view of philosophy as a progressive science. In section II, I quoted Putnam's description of the central features of analytic philosophy in the 1950s and 1960s. A decade or so after Putnam wrote these words, a new understanding of philosophy (re-)emerged:

There is a consensus, at least among [the] select group of philosophers [who contributed to Philosophy in History], that the discipline of philosophy as recently practiced in the Anglo-American context has been much too narrow in scope and outrageously pretentious and anachronistic in its claims. It has focused on obscure linguistic and logical issues tied to the epistemological project of articulating the conditions of certain knowledge, defined these issues as the eternal questions of philosophy, and reconstructed the history of philosophy as successive attempts to answer these questions. The historical perspective is put into operation to reveal the historically contingent nature of this definition of philosophy and philosophical problems, to open up the discipline to a range of new questions (relating to the interpretation of meaning, ethics, and politics) as well as to methods for approaching and writing about such questions. At issue is not simply the revision and enrichment of the history of philosophy through the expansion of its canon of relevant thinkers and questions, but the reformulation of the nature of philosophy as a cultural activity. The conventional analytic distinction between the validity and the historical genesis of truth claims is rejected. ${ }^{25}$

Postema recently endorsed such a view when he wrote that 'philosophy [in general] is constitutionally historical'. ${ }^{26}$ There is a weak and strong way of understanding this more historically-informed approach to the study of ideas. The weak version asserts that to comprehend what, say, Hobbes wrote, we should not think of him as engaged in debates that were hardly conceived of when he was writing. ${ }^{27}$ In this weak version, even philosophers who think they are engaged in timeless questions, even those who think they are writing for the ages, are products of their age, and their works may be far more parochial than they are aware of. Thus, to understand Hobbes, we should pay attention to his actual debates with his contemporaries, not to conjectured debates with ours.

This mildly historicist view is still consistent with the idea that there is a core of fairly stable philosophical questions that philosophers have always been concerned with, as well as that law's nature remains constant. One needs to

\footnotetext{
${ }^{25} \mathrm{JE}$ Toews, 'Intellectual History after the Linguistic Turn: The Autonomy of Meaning and the Irreducibility of Experience' (1987) 92 American Historical Review 879, 905. The book referred to in the quote is R Rorty et al (eds), Philosophy in History: Essays on the Historiography of Philosophy (Cambridge University Press 1984).

${ }^{26}$ GJ Postema, 'The Data of Jurisprudence' (2018) 95 Washington University Law Review 1083, 1088. Postema adds (ibid), 'The long tradition of philosophy is the tradition of engaging continually with its tradition, and this engagement of philosophy in its history is always philosophical, and hence resolutely critical.'

${ }^{27}$ See Q Skinner, Visions of Politics: Regarding Method (Cambridge University Press 2002) 59-61.
} 
be better versed in the historical context in which particular theorists wrote to understand how past thinkers sought to answer these questions, but the questions remain enduring. So understood, this critique of timeless philosophy is rather limited. That is why it is better to understand the historicist critique as presenting a stronger challenge. It is not just that the answers philosophers offer are contextual, their questions and object are contextual too. It makes little sense to study Plato as if he is addressing contemporary philosophical concerns, because the questions and problems that past philosophers have addressed were the questions and problems of their time. In a famous critique of the timeless approach to the study of past thinkers, Quentin Skinner attacked the tendency to think of philosophical classics as concerned with 'timeless questions and answers', arguing that there are no 'perennial problems in philosophy'. ${ }^{28}$ On the basis of a very similar foundation of Hart's work - the philosophy of language of Wittgenstein and JL Austin - Skinner has doubted the very possibility of 'trying definitely to fix the analysis of key moral terms. ${ }^{29}$ These different contexts and concerns suggest that the subject-matter of inquiry, despite being denoted with the same word, is not the same.

Now comes a surprise. For many of those who have supported the progressivescience conception of jurisprudence have also emphasised its 'hermeneutic' (in plainer English, 'interpretive') nature. This is surprising because a hermeneutic understanding of jurisprudence seems closer to the contextual inquiry considered here, and thus to push against the progressive-science model. To demonstrate this tension, I will make a detour to the philosophy of history, an area of philosophy not frequently discussed together with jurisprudence, but which I think bears important resemblance to some debates in jurisprudence, and one that is particularly pertinent in the context of examining the relationship between jurisprudence and time. This detour will show another benefit of greater familiarity with the history of philosophy, and the philosophy of history. As mentioned, the ahistorical conception of jurisprudence tends to be uninterested in the subject's own history. Consequently, The Concept of Law ends up being treated as a book that first mapped an uncharted land, nothing less than 'an authentic "Eureka!" moment in the history of ideas', ${ }^{30}$ ignoring its own intellectual history. ${ }^{31}$ Examining that reveals a book that is far less original than it is often taken to be. One aim of the ensuing discussion is that ideas treated as philosophical breakthroughs were familiar in other areas of philosophy when Hart wrote them.

\footnotetext{
${ }^{28}$ ibid 88. Q Skinner, 'Meaning and Understanding in the History of Ideas' (1969) 8 History and Theory 3, 5, 50. Skinner here was explicitly following Collingwood. On the significance of this point, see the discussion in text accompanying nn 35-39 below.

${ }^{29}$ See Skinner (n 27) 103, 177.

${ }^{30}$ J Gardner, 'Why Law Might Emerge: Hart's Problematic Fable' in LD d'Almeida et al (eds), Reading HLA Hart's The Concept of Law (Hart Publishing 2013) 81, 96.

${ }^{31}$ cf Dan Priel, 'HLA Hart and the Invention of Legal Philosophy' (2011) 5 Problema 301.
} 
If one thinks of jurisprudence (as Kelsen did) as the science of norms, one that is in no way dependent on any psychological attitudes or any internal point of view', the disregard of the philosophy of history seems to make sense. But if one thinks of law as a social phenomenon, and jurisprudence as part of the effort of explaining it, then the connection with history and its philosophical study becomes more apparent. For history is the attempt to explain human actions, to describe historical processes; against this, the philosophy of history asks what constitutes a good explanation of these 'historical' events. Law involves human action, which jurisprudence tries to organise and explain. Methodological debates in jurisprudence then ask what constitutes a good explanation of these 'legal' events. So understood, jurisprudence and the philosophy of history can be seen as branches of the philosophy of social explanation. One particular question asked in both areas has to do with the applicability of explanatory methods and models derived from the natural sciences to human affairs.

This is the relevant intellectual backdrop for considering Hart's methodological insistence on the importance of accounting for the 'internal aspect' of human action. In the Preface to The Concept of Law, Hart wrote that the book could be understood as an essay in 'descriptive sociology'. And the proper way to do that, he wrote, requires recognising that 'neither law nor any other form of social structure can be understood without an appreciation of certain crucial distinctions between two different kinds of statement, which I have called "internal" and "external" and which can both be made whenever social rules are observed'. ${ }^{32}$ As the italicised words make clear, Hart was here making a general claim about the explanation of all social phenomena. It is the inherent inadequacy of external explanations that led Hart to say a few decades later that the methods of the 'empirical sciences are useless' for explaining normative behaviour. ${ }^{33}$

Hart considered the 'internal point of view' the most important idea of The Concept of Law. Others concurred: Scott Shapiro, for example, described it as 'perhaps Hart's greatest contribution to jurisprudential theory'. ${ }^{34}$ Historical context helps put this idea in its place. Writing some years before Hart, the Oxford philosopher and historian RG Collingwood had this to say of the task of the historian:

The historian, investigating any event in the past, makes a distinction between what may be called the outside and the inside of an event. By the outside of the even I mean everything belonging to it which can be described in terms of bodies and their

\footnotetext{
${ }^{32}$ Hart (n 14) vi (emphasis added).

${ }^{33}$ HLA Hart, Essays in Jurisprudence and Philosophy (Clarendon Press 1983) 13.

${ }^{34}$ SJ Shapiro, 'The Bad Man and the Internal Point of View' in SJ Burton (ed), The Path of the Law and Its Influence: The Legacy of Oliver Wendell Holmes, Jr (Cambridge University Press 2000) 197, 197.
} 
movements ... By the inside of the event I mean that in it which can only be described in terms of thought ... [The historian's work] may begin by discovering the outside of an event, but it can never end there; he must always remember that the event was an action, and that his main task is to think himself into this action, to discern the thought of its agent. In the case of nature, this distinction between the outside and the inside of an event does not arise. The events of nature are mere events, not the acts of agents whose thought the scientist endeavours to trace. ${ }^{35}$

To anyone with even a passing familiarity with Anglophone jurisprudence of the last few decades, these words are bound to sound familiar, as will also be the following words:

In thus penetrating to the inside of events and detecting the thought which they express, the historian is doing something which the scientist need not and cannot do. ... [T] he historian need not and cannot (without ceasing to be an historian) emulate the scientist in searching for the causes or laws of events. For science, the event is discovered by perceiving it, and the further search for its cause is conducted by assigning to it its class and determining the relation between that class and others. For history, the object to be discovered is not the mere event, but the thought expressed in it. To discover that thought is already to understand it. After the historian has ascertained the facts, there is no further process of inquiring into their causes. When he knows what happened, he already knows why it happened ... The cause of [an] event, for [a historian], means the thought in the mind of the person by whose agency the event came about: and this is not something other than the event, it is the inside of the event itself. ${ }^{36}$

Collingwood, like Hart after him, was trying to articulate the idea that to understand human action is to understand 'the thought in the mind' of the person who made it in terms of reasons for action. That is a classic statement of a humanistic conception of social explanation, concerned not with identifying some general laws of human behaviour, nor with predicting human action, but with 'the inside of events'. In both history and jurisprudence, this view has been the basis for challenges to attempts to align these disciplines with the natural sciences.

It is quite clear that Hart was familiar, at least indirectly, with Collingwood's views. ${ }^{37}$ But the origins of the internal point of view are far older than that. The distinction between an internal and an external point of view, and the insistence of the importance of the former for the explanation of purposive human

\footnotetext{
${ }^{35}$ RG Collingwood, The Idea of History (Clarendon Press 1946) 213-14.

36 ibid 214-15. Compare this to Hart's remarks on the explanation of human action in Hart (n 14) $88-90$.

${ }^{37}$ Collingwood's views were further defended in W Dray, Laws and Explanation in History (Clarendon Press 1957) 124, 128, 130, 133; and PH Nowell-Smith, 'Are Historical Events Unique?' (1957) 57 Proceedings of the Aristotelian Society 107. Both sources are cited approvingly in HLA Hart and AM Honoré, Causation in the Law (Clarendon Press 1959) 8, fn 3.
} 
behaviour can be traced to eighteenth-century German philosophy. Here is how a modern commentator summarised the ideas of Johann Gottfried Herder (1744-1803):

[W] hat distinguishes human agency, so Herder argued, is its capacity for meaning, for which the use of language is crucial and no naturalistic, mechanical account of language is adequate to capture that sense of meaning. What we mean by words depends on an irreducible sense of normativity in their use, and our grasp of such normativity itself depends on our immersion in a way of life (a 'culture'), which functions as a background to all our more concrete uses of language. Since meaning and the expression of meaning is critical to understanding agency, and meaning is irreducibly normative, no third-person, purely objective understanding of agency is possible; one must understand both the agent's culture and the agent himself as an individual from the 'inside,' not from any kind of external, third-person point of view. ${ }^{38}$

Herder was one of the founders of the study of 'hermeneutics', the theory of interpretation of texts and, eventually, of all human action and history. These ideas were then taken up by others. Worthy of a longer discussion than I give him here is Wilhelm Dilthey (1833-1911). Dilthey is significant, because he serves as one possible link between German philosophy and Collingwood, and thus Oxford. ${ }^{39}$ Dilthey is especially interesting because in his work he contrasted what he called 'explanatory psychology', whose methods and aspirations were borrowed from the natural sciences, with a different approach, which he called 'descriptive and analytic' psychology, which was the appropriate method for humanistic study. ${ }^{40}$ Even if coincidental, the similarity between this and Hart's terminology for his own work as both descriptive sociology and analytic philosophy is noteworthy.

I do not suggest any stronger influence, as demonstrating that is always tricky. To the best of my knowledge, Hart never made any reference in his writings to the work of either Herder or Dilthey; and I am not claiming any unacknowledged borrowing on his part. I doubt that Hart would have found everything Herder or Dilthey wrote congenial. However, it is inescapable that Hart explicitly associated himself with a 'hermeneutic' approach. ${ }^{41}$ Though he made the reference only quite late in his career, and possibly after seeing

\footnotetext{
${ }^{38}$ T Pinkard, German Philosophy 1760-1860: The Legacy of Idealism (Cambridge University Press 2002) 133. As Pinkard acknowledges, others have read Herder differently, but it suffices for my argument that others have read Herder in this way. Particularly relevant for my point in the text following is that Wilhelm Dilthey saw Herder as an ancestor. See K Gjesdal, 'Hermeneutics and the Human Sciences' in MN Forster and K Gjesdal (eds), The Cambridge Companion to Hermeneutics (Cambridge University Press 2019) 354, 364-66.

${ }^{39}$ Collingwood (n 35) 171-76, offers a short and largely sympathetic discussion of Dilthey.

${ }^{40}$ See W Dilthey, 'Ideas Concerning a Descriptive and Analytic Psychology' in Descriptive Psychology and Historical Understanding, trs RM Zaner and KL Heiges (Martinus Nijhoff 1977) 23, 53 ('Contrary to outer perception, inner perception rests on an inner awareness, a lived experience').

${ }^{41}$ See Hart (n 33) 13; see also ibid 162.
} 
it in others' discussion of his work ${ }^{42}$ this was no accidental reference. It fits with ideas that we do know Hart was familiar with coming from the work of Wittgenstein (both directly and via the work of Peter Winch), as well as Max Weber and Collingwood. ${ }^{43}$ (In section IV, I suggest another possible source for Hart's method.)

In somewhat different ways, these thinkers have distinguished between 'explanation' (Erklären), relevant for accounting for the natural world, and 'understanding' (Verstehen) as its equivalent in the domain of human thought. ${ }^{44}$ One specific way in which the distinction between the social scientific and the hermeneutic methods of inquiry has been drawn was in terms of a categorical distinction between reasons and causes: the natural world was governed by causes, social reality was governed by reasons. ${ }^{45}$ Consequently, many concluded that the attempt to use the methods of the natural sciences to explain human action was misconceived.

Hart made a few short but quite clear references to this distinction in The Concept of Law. There is a more elaborate discussion of this point in Causation in the Law, co-authored with Tony Honore and published two years earlier. In that book, drawing explicitly on contemporary writings in the philosophy of history, Hart and Honoré argued that law, like history, is concerned with the explanation of human events, and more specifically with particular human events. ${ }^{46}$ As such, they argued that human action cannot be explained in terms of general causal laws of the kind that we find in the natural sciences.

\footnotetext{
${ }^{42}$ See PMS Hacker, 'Hart's Philosophy of Law' in PMS Hacker and J Raz (eds), Law, Morality, and Society: Essays in Honour of HLA Hart (Clarendon Press, 1977) 1, 12; N MacCormick, HLA Hart (Edward Arnold 1981) 37-38.

${ }^{43}$ On Wittgenstein's links to German hermeneutics, see the brief remarks in PMS Hacker, Wittgenstein: Connections and Controversies (Oxford University Press 2001) 37, 57-58, 66 (arguing that Wittgenstein's later philosophy is committed to the 'autonomy of humanistic understanding against the illegitimate encroachment of the natural sciences'). Winch's Wittgenstein-influenced ideas on the social sciences are found in P Winch, The Idea of a Social Science and Its Relation to Philosophy (Routledge \& Kegan Paul 1958), cited in Hart (n 14) 289, 297. On the connection between Hart and Weber, see H Ross, Law as a Social Institution (Hart Publishing 2001); see also BZ Tamanaha, "The Internal/External Distinction and the Notion of a "Practice" in Legal Theory and Sociolegal Studies' (1995) 30 Law and Society Review 163, 186-88 (situating Hart within sociological debates on the internal/external point of view).

${ }^{44}$ See, eg, GH von Wright, Explanation and Understanding (Cornell University Press 1971) 4-7; cf Q Skinner, 'Hermeneutics and the Role of History' (1975) 7 New Literary History 209, 209-11.

${ }^{45}$ See, eg, AI Melden, Free Action (Routledge \& Kegan Paul 1961) ch 14; AR Louch, Explanation and Human Action (University of California Press 1966); Dray (n 37); R Abelson, “"Because I Want to"' (1965) 73 Mind 540, 541, passim; JO Urmon, 'Motives and Causes' (1952) 26 Proceedings of the Aristotelian Society Supplement 179, 191-94. An exceptionally clear, brief exposition of this view appears in R Abelson, 'Book Review' (1963) 23 Philosophy and Phenomenological Research 616; cf Collingwood (n 35) 214 ("words like "cause" are [not] necessarily out of place in reference to history; [but] they are used there in a special sense').

${ }^{46}$ See Hart and Honoré (n 37) 8-9, 48-55.
} 
Hart is not alone in associating jurisprudence with hermeneutics. After a heavily Kelsen-inspired (and quite clearly anti-hermeneutic) stage in his early work, Joseph Raz moved much closer to interpretivism, including drawing a link between jurisprudence and hermeneutics. ${ }^{47}$ Raz argued that jurisprudence aimed at illuminating an aspect of human life by trying to 'advance our understanding of society by helping us understand how people understand themselves'. ${ }^{48}$ He contrasted this form of explanation with the explanation of electrons, whose nature is independent of what people think about them. Once again, these ideas will sound familiar to those who know Collingwood's views on historical explanation, which he justified by the human desire for self-knowledge. 'Self-knowledge', he explained, does not mean knowledge of humans' 'bodily nature', nor does it mean knowledge of sensation and emotion (as such), but rather it is 'knowledge of [humans'] knowing faculties, [their] thought or understanding or reasons' ${ }^{49}$ This knowledge, Collingwood believed, could not be attained by imitating the methods of the natural sciences. ${ }^{50}$

It is time to return to the problem raised earlier. From a hermeneutic perspective, the separation between legal philosophy and legal history, and with it the search for timeless truths, looks suspect. The hermeneutic, internal approach has been a central plank of Herder's philosophy of history, and served him to argue that different nations and different cultures are fundamentally different, and that therefore they can only be understood by attending to their own self-understandings. ${ }^{51}$ Since important social practices like law are bound with

\footnotetext{
${ }^{47}$ See Raz (n 24) 48, fn 5. Raz has in fact argued that Hart's rejection of the methods of the natural sciences did not go far enough. He attributed Hart's errors to his 'adherence to naturalism and empiricist epistemology, and his rejection of evaluative objectivity': ibid 52.

${ }^{48} \mathrm{~J}$ Raz, Ethics in the Public Domain: Essays in the Morality of Law and Politics (rev edn, Clarendon Press 1995) 237. And see further his remarks in Raz (n 24) 96-97, where he says that 'the way a culture understands its own practices and institutions is not separate from what they are'. See also L Green, 'The Concept of Law Revisited' (1996) 94 Michigan Law Review 1687, 1717 (the value of jurisprudential inquiry lies in 'help[ing] us understand our institutions and, through them, our culture'). Add to it that jurisprudential thought is part of that culture and the difficulties with timeless jurisprudence become evident. For comparison, substitute 'art' for 'law'.

${ }^{49}$ Collingwood (n 35) 205.

${ }^{50}$ See ibid.

${ }^{51}$ MN Forster, 'Introduction' in JG von Herder, Philosophical Writings, ed and tr MN Forster (Cambridge University Press 2002) vii, xiv-xv, xxv; I Berlin, Three Critics of the Enlightenment: Vico, Hamann, Herder (2nd edn, Princeton University Press 2013) 232-37. Consequently, according to Berlin's reading of Herder, '[p]articular words are used in communicating particular experiences as a result of ... environmental factors ... or of psychological ones; or of mere chance; or of the decisions of human beings, who acquiring some terms by 'natural' means ... invent others as they please, arbitrarily. That is why the doctrine of real essences - the ... plan of discovering the truth by the analysis of concepts - is a chimera' (ibid 192). Certain aspects of Berlin's interpretation of Herder have come under serious criticism. See, eg, J Israel, 'Foreword', ibid ix, xv; RE Norton, 'The Myth of the Counter-Enlightenment' (2007) 68 Journal of the History of Ideas 635, 644-50; but cf FC Beiser, The German Historicist Tradition (Oxford University Press 2011) 133 (describing 'Herder's critique of Enlightenment historiography'). But even Berlin's critics acknowledge that later scholars, especially Dilthey, accepted some of the views Berlin attributed to Herder. See Norton ('The Myth of the Counter-Enlightenment') 652.
} 
different groups' culture and history, they are embedded in their particular historical context. And indeed, the central ideas of the German historical school of jurisprudence can be traced to Herder's writings about nation and national spirit. ${ }^{52}$ In more modern parlance, we would speak of law as a product of, or at least imbued by, local culture, precisely what hermeneuticists have maintained an 'external', scientific perspective cannot adequately account for.

All this has profound significance for thinking about jurisprudence in time, since it is a central point of historical thinking from the internal point of view that it is wrong to seek law-like universal explanations of historical phenomena and ideas, and that it is wrong to think about concepts, practices, institutions and ideas outside time. Thus, to fully understand Roman law, one has to understand the particular cultural context in which it existed. And this goes beyond understanding the cultural significance of particular legal institutions that Roman law recognised (eg slavery). It goes to the way the Romans understood the idea of law and its place within the universe. If, for example, some form of natural law theory was dominant among Roman lawyers, this is not just a sociological observation, which we can judge as a mistaken belief about the timeless nature of law. Rather, we must try and understand how this fact figured in Romans' understanding and practice of law 'from the internal point of view'.

\section{RECONCILIATION?}

The story so far: There is an 'official view' according to which history does not matter to jurisprudence, as the two are largely independent inquiries. But underneath it lurks a different story, where it seems history plays a more significant role. In describing Herder's thought, one commentator wrote that

he takes relatively little interest in the 'great' political and military deeds and events of history, focusing instead on the 'innerness' of history's participants ... Because of it, psychology and interpretation inevitably take center-stage in the discipline of history for Herder. ${ }^{53}$

Turning to our time, Collingwood's ideas served as the inspiration to many in the 'Cambridge school' of history of ideas, an approach that is most associated with the view that political ideas and concepts are embedded in their time. ${ }^{54}$

Given Hart's views on the necessity of adopting a very similar hermeneutic approach to jurisprudence, should the same not be true of jurisprudence? To put it plainly, it is not easy to see a way out of the tension between, on the one hand,

\footnotetext{
${ }^{52}$ See I Berlin, Political Ideas in the Romantic Age: Their Rise and Influence on Modern Thought, ed H Hardy (2nd edn, Princeton University Press 2014) 233-34; Beiser (n 51) 216-17.

${ }^{53}$ Forster (n 51) xxv.

${ }^{54}$ See Q Skinner, 'The Rise of, Challenge to and Prospects for a Collingwoodian Approach to the History of Political Thought' in D Castiglione and I Hampsher-Monk (eds), The History of Political Thought in National Context (Cambridge University Press 2001) 175, 175-77.
} 
a commitment to a hermeneutic methodology, justified by the fact that law is a 'self-reflective activity', and, on the other hand, the claim that legal philosophy is fundamentally different from legal sociology, because it seeks to identify the universal and necessary features about law, which exist independently of people's attitudes.

Here is another way of demonstrating the tension. In presenting the progressive-science view of jurisprudence, I wrote in section II that that view is not 'that laws, or even that prevailing ideas about law, do not change. Rather, the thought is that underneath these changes, there is a single, unchanging nature that law in all times and places possesses, one that exists, as it were, outside of time and space.' These words keep the prevailing views about law completely separate from the nature of law itself. But if, as the hermeneutic approach suggests, the nature of law is constituted by attitudes about the practice, then the separation breaks down. In that case, it is far more difficult to think, substantively, that law has an unchanging nature; and methodologically, it is far more difficult to keep the philosophical search for law's unchanging nature separate from the sociological inquiry into changing attitudes about it.

Surprisingly, many legal philosophers have adopted these seemingly conflicting positions without acknowledging, let alone trying to resolve, their tension. They in effect hold that the attitudes that happen to be shared by all about law (assuming there are any) are also the ones that constitute the nature of law, even though stating so may require ignoring people's own views on law's essential features (which may change with time and place). One place where this tension comes to light is in the reactions of many legal philosophers to the work of Ronald Dworkin. While sharing with him the commitment to jurisprudence as a hermeneutic (interpretive) enterprise, critics nevertheless dismissed his work as not really jurisprudence. In their judgment, Dworkin's work was too local, too close to actual practice to count as philosophy. ${ }^{55}$ And his view that jurisprudence is continuous with legal doctrine ${ }^{56}$ was widely criticised as confused. But if legal philosophers take their commitment to a hermeneutic approach and the internal point of view as seriously as they proclaim, then Dworkin seems to have the upper hand. For in essence, Dworkin's critics are saying that legal philosophers should ignore those attitudes that do not fit their working assumption that law has a single nature.

Is there a way of avoiding these problems? In a book published just two years before The Concept of Law, Hart's friend and colleague, Peter Strawson, made some methodological remarks that might be read as offering a way of resolving the tension. In the opening pages of his book Individuals: An Essay in

\footnotetext{
${ }^{55}$ See J Dickson, Evaluation and Legal Theory (Hart Publishing 2001) 22-23 and fn 31; Gardner (n 20) 184. For similar reasons, one of Postema's essays was also singled out for holding a 'fundamentally anti-philosophical' stance: ibid 24 and fn 6.

${ }^{56}$ R Dworkin, Law's Empire (Harvard University Press 1986) 90. Dworkin openly acknowledged his allegiance with the German hermeneuticists: ibid 62, 419-20, note 2.
} 
Descriptive Metaphysics, Strawson explained what he meant by his subtitle by drawing the following contrast: 'Descriptive metaphysics is content to describe the actual structure of our thought about the world, revisionary metaphysics is concerned to produce a better structure. ${ }^{, 57}$ In explaining how such a 'descriptive' inquiry is to be done, Strawson wrote that it begins with 'a close examination of the actual use of words', as it 'is the best, and indeed the only sure, way in philosophy. ${ }^{, 58}$ But because of the depth of the inquiry, he added, one must go beyond language. Linguistic practices, 'however revealing at a certain level, are apt to assume, and not to expose, those general elements of structure which the metaphysician wants revealed. The structure he seeks does not readily display itself on the surface of language, but lies submerged. ${ }^{59}$

This is similar to the distinction legal philosophers draw between what they are doing (conceptual analysis) and linguistics. ${ }^{60}$ But this does not resolve a different difficulty this approach faces, that of explaining 'conceptual change'. For even if we go beyond immediate linguistic practices, the possibility of deeper conceptual change remains open. Strawson readily acknowledged that concepts change, 'though mainly, on the specialist periphery'. Nevertheless,

it would be a great blunder to think of metaphysics only in this historical style. For there is a massive central core of human thinking which has no history - or none recorded in histories of thought; there are categories and concepts which, in their most fundamental character, change not at all. Obviously these are not the specialities of the most refined thinking. They are the commonplaces of the least refined thinking; and are yet the indispensable core of the conceptual equipment of the most sophisticated human beings. ${ }^{61}$

Strawson's claim, if true, accepts that, in general, social phenomena must be understood in their particular context, and that normally that would imply that there are no universal explanations of most concepts referring to social institutions, only culturally-specific ones. At the same time, Strawson maintained that some exceptional concepts have 'no history', and therefore do not change.

\footnotetext{
${ }^{57}$ PF Strawson, Individuals: An Essay in Descriptive Metaphysics (Methuen 1959) 9. It is worth pointing out that Strawson thanked Hart for his comments on the manuscript: ibid 3. Hart, in turn, thanked Strawson in the Preface of The Concept of Law for his comments on his text. See Hart (n 14) vii. The connection between Strawson's project and Hart's was first noted in J Mikhail, “"Plucking the Mask of Mystery from Its Face": Jurisprudence and HLA Hart' (2007) 95 Georgetown Law Journal 733, 748.

${ }^{58}$ Strawson (n 57) 9; cf Hart (n 33) 2-4.

${ }^{59}$ Strawson (n 57) 10. Again, it is interesting to compare this work to Herder's idea, who wrote that in his conception of philosophy, 'metaphysics become[s] a philosophy of human language'. See JG Herder, 'Selections from A Metacritique of the Critique of Pure Reason' in JP Surber (ed), Metacritique: The Linguistic Assault on German Idealism (Humanity Books 2001) 89, 90 (emphasis omitted).

${ }^{60}$ See Raz (n 24) 53-6; KE Himma, 'Reconsidering a Dogma: Conceptual Analysis, the Naturalistic Turn, and Legal Philosophy' (2007) 10 Current Legal Issues 3, 10-11.

${ }^{61}$ Strawson (n 57) 10.
} 
The argument now to be made on behalf of Hart and others seeking to combine essentialism with hermeneuticism is that law happens to be one of those concepts without history. Though he does not say so explicitly in the original text of The Concept of Law, in the posthumous remarks published as the Postscript to the book, Hart said just that: 'in spite of many variations in different cultures and in different times, [law] has taken the same general form and structure' ${ }^{62}$

Admittedly, this remark is made in a different context, so it takes some interpretive licence to use it as a basis for extending Strawson's view to Hart. The bigger problem is that it is difficult to think of law as one of those concepts that have no history and that do not change. Law seems to fit better within Strawson's other category of concepts, that of the 'specialities' of refined thinking. For instance, the list of beliefs about law that Hart attributes to 'educated people' (so neatly matching the questions his book would later address) is in some ways representative of the law of a modern state, but does not fit other contexts, as Hart himself conceded when he discussed the law of pre-modern societies and international law. ${ }^{63}$ This suggests that despite the superficial similarity between Strawson's descriptive metaphysics and Hart's descriptive jurisprudence, the attempt to rely on the former to solve the inherent tension in the latter does not work.

\section{THREE CHALLENGES TO TIMELESS JURISPRUDENCE}

This failed attempt at reconciliation leaves us where we were before, with what looks like an unresolvable tension at the heart of contemporary jurisprudence. In this section, I consider three possible ways of confronting this tension, three different ways in which time might figure more prominently in jurisprudential inquiry. First, it might be argued that as a matter of fact law has a temporal component, and therefore no adequate account of law can fail to acknowledge this fact. A second, stronger, claim is that all law necessarily has a temporal component, because law's normative force takes place in time. Finally, one may reject the assumption that law has an unchanging nature. Law is always a product of a particular culture, and like other cultural phenomena, law has a temporal (and geographical) nature. This implies that the proper method for studying law should be the same as the one adopted for the study of other cultural phenomena: historical, situated, contingent. It is here that I come to consider Postema's contributions to the subject, because in different works he made remarks that can be read as supporting all three claims.

\footnotetext{
${ }^{62}$ Hart (n 14) 240.

${ }^{63}$ See ibid 3, 156, 234-37.
} 


\section{A. The Common Law as a Time-Bound Authority}

One path to challenging the ahistoricity of jurisprudence accepts some version of the search for a general, cross-cultural account of law, but insists that, at least in some places, law is a time-constrained phenomenon. This challenge can be gleaned from Postema's pioneering work on what he called 'common law theory' ${ }^{64}$ In this vein Postema can be read as arguing that if we look seriously and carefully at past practices that we call 'law', practices that we treat as ancestors of those phenomena in today's world that we think of as law, we find aspects of them that do not fit with currently-dominant theories of law. Instead, they fit better into a distinct legal theory. These ideas cannot be dismissed (as the progressive-science approach would suggest) as errors of less informed individuals. Rather, they look like a relatively coherent and well-worked out theory of law. Postema identified in the writings of prominent English lawyers like Edward Coke, John Selden and Matthew Hale a distinct theory of law, not reducible to either legal positivism or natural law theory. ${ }^{65}$

At a minimum, this work poses a challenge to those who look at legal positivism and natural law theory as exhausting the theoretical terrain of theories of law, thus showing how a historically-informed philosopher can come to challenge prevailing views. To illustrate the difference, consider the relationship between law and rules. In modern thinking the relationship is axiomatic, indisputable. Scott Shapiro, for example, asked, 'what else does the law consist in if not rules?' 66 The answer, common law theorists would have said, is, 'well, not rules': In the words of Postema, in this conception of law, law is 'not a set of rules or laws, but a practised framework of practical reasoning', which 'constitutes a form of social ordering'. ${ }^{67}$ Thus, greater familiarity with past legal phenomena can enrich one's thinking about law. But time figures in this challenge in a more substantial way: In common law theory, law develops by a slow process of incremental changes and receives its authority neither from its sources (as positivists have it) nor from its inherent rationality (as natural law theorists argue), but from its historical provenance (and possibly its social acceptance). As Postema put it, ' $[\mathrm{t}]$ he reason of the Common Law is ... historical'. ${ }^{68}$ In this conception of law, time and history are inherent to the law's authority.

\footnotetext{
${ }^{64}$ See generally GJ Postema, Bentham and the Common Law Tradition (2nd edn, Oxford University Press 2019) 3-38; GJ Postema, 'Classical Common Law Jurisprudence (Part I)' (2002) 2 Oxford University Commonwealth Law Journal 155 (2002); GJ Postema, 'Classical Common Law Jurisprudence (Part II)' (2003) 3 Oxford University Commonwealth Law Journal 1.

${ }^{65}$ See GJ Postema, 'The Philosophy of the Common Law' in Oxford Handbook (n 8) 588, 599; cf HJ Berman, 'The Origins of Historical Jurisprudence: Coke, Selden, Hale' (1994) 103 Yale Law Journal 1651, 1652.

${ }^{66}$ SJ Shapiro, 'The "Hart-Dworkin" Debate: A Short Guide for the Perplexed' in A Ripstein (ed), Ronald Dworkin (Cambridge University Press 2007) 22, 26. This, of course, was Hart's view as well.

${ }^{67}$ Postema, 'Classical Common Law (Part II)' (n 64) 14.

${ }^{68}$ Postema, Bentham and the Common Law Tradition (n 64) 37.
} 
I think Postema's work here served as an important corrective to so much contemporary legal theory that either ignores the common law altogether or tries to squeeze it into the two more familiar categories. ${ }^{69}$ But common law theory describes a practice that, in the words of Holmes, 'did not begin with a theory', and never fully worked out one. ${ }^{70}$ The common law, and its theory, remain elusive, because they reflect a never-ending project, a constant chase after decisions, which themselves struggle to catch up with changing reality. It is a theory of a practice that is in an important sense opposed to theorising, at least the timeless theorising of the kind Nietzsche attacked. ${ }^{71}$ On this view, the law gets its authority from the environment (and history) in which it exists, but since this keeps changing, the law is in an endless chase with reality.

\section{B. Three Paths to the Normativity of Law}

Recognising that the common law reflects a distinct approach to the authority of law is a good starting point for a broader discussion of the significance of time on law's authority. In the last section I invoked the two war horses of legal theory, legal positivism and natural law theory. The standard way of thinking of legal positivism and natural law theory is as competing theories, such that if one is right, the other is necessarily false. A second approach is to try and reconcile them, to suggest that they are complementary in that each contains part of the truth, or that they are ways of looking at the same phenomena from different perspectives. ${ }^{72}$ These solutions are in principle possible when we add common law theory to our menu of possible (competing) theories.

\footnotetext{
${ }^{69}$ For further illustration, in an essay that builds on Postema's work on common law theory, see D Priel, 'Not All Law is an Artifact: Jurisprudence Meets the Common Law' in L Burazin et al (eds), Law as an Artifact (Oxford University Press 2018) 239.

${ }^{70}$ OW Holmes, The Common Law (Little, Brown 1881) 77. Holmes says this with respect to tort law, but this is a fair statement of the common law in general.

${ }^{71}$ Ideas similar to (and to some extent influenced by) common law theory developed in nineteenthcentury Germany. The most important figure in their development was Friedrich Karl von Savigny. Savigny's prominence extended well beyond Germany and even cast some influence on common law jurisdictions, for example in debates in the United States over codification. See M Reimann, 'The Historical School Against Codification: Savigny, Carter, and the Defeat of the New York Civil Code' (1989) 37 American Journal of Comparative Law 95. Interestingly, Jhering stated that for Savigny 'laws are not made, but rather become'. R Berkowitz, 'From Justice to Justification: An Alternative Genealogy of Positive Law' (2011) 1 University of California at Irvine Law Review 611, 625 (quoting Rudolf von Jhering, 'Friedrich Karl Von Savigny' (1861) 5 Jahrbücher für die Dogmatik des heutigen römischen und deutschen Privatrechts 354, 364-65). This contrast between 'being' and 'becoming' is precisely the one Nietzsche invoked when he criticised philosophers' 'hatred of the very idea of becoming', in the quotation accompanying $\mathrm{n} 1$.

${ }^{72}$ For an example of the first strategy see Gardner (n 20) vii-viii (claiming to borrow from both legal positivism and natural law); for an example of the second strategy, see L Alexander and E Sherwin, The Rule of Rules: Morality, Rules, and the Dilemmas of Law (Duke University Press 2001) 196-98.
} 


\section{Dan Priel}

There is, however, a different way of thinking about these different approaches, the one I want to pursue here. And that is that different theories may not equally fit the law in different times and places. So understood, the word 'law' will refer to several different things that belong to different categories. Some have argued this view is incoherent. John Gardner, for instance, stated that 'If law is not a valid classification, then nor is Cheyenne law, international law, Scots law, shari'a law, or Roman law. If there is no general jurisprudence ... then there is also no special jurisprudence. ${ }^{73}$ But this is a mistake. It is perfectly coherent to think that the word 'law' is ambiguous, and that different things we call 'law' belong to different categories and that law (in general) is a disjunctive category. It is also possible to tell a historical, evolutionary story, in which one dominant form of law replaces another.

Where does Postema stand on this debate? Postema associates the insights of the time-based view of law with seventeenth- and eighteenth-century English legal scholars. One may add to them some members of the historical school of jurisprudence, particularly dominant in the middle of nineteenth-century Germany. ${ }^{74}$ From the perspective of the progressive-science model of jurisprudence, these theories may be understood as correct or incorrect descriptions of what law is, but descriptions that leave the practice of law largely intact. But if we take seriously the view that different legal philosophies manifest themselves in different understandings or conceptualisations of law and its role in society, different jurisprudential theories will result in somewhat different legal practices. The main proponents of common law theory were lawyers who developed their ideas against the background of a particular legal system. They thus had a role both in shaping the law and theorising it. This would suggest that it would be difficult to see timebased conceptions of law as capturing the essence of law in times and places where other ideas were dominant. Moreover, especially given that appeals to 'tradition' are almost always bound with a certain view of politics as represented in the work of Edmund Burke, ${ }^{75}$ it is inviting to think of time-bound authority as reflecting a view that may be true of a particular socio-political tradition, not something that captures necessary features of law true in all political environments.

Between these two possibilities - one where the time-boundedness of law is one possible conception and one where it is part of the essence of law - Postema is not entirely clear. He writes in one place that ' $\mathrm{t}]$ he philosophical explanation of law ... seeks a general account of a concept deeply embedded in the intellectual and political traditions of our culture and the day-to-day activities and social interactions shaped by them' ${ }^{76}$ At the same time, Postema seems to

\footnotetext{
${ }^{73}$ See Gardner (n 20) 279.

${ }^{74}$ See Berman (n 65) 1736-37. See also n 71 above.

${ }^{75}$ The link is explicit in Kronman (n 7) 1048-64. It also figures prominently in critiques of Kronman's views. See D Luban, 'Legal Traditionalism' (1991) 43 Stanford Law Review 1035, 1055-57; N Duxbury, 'History as Hyperbole' (1995) 15 Oxford Journal of Legal Studies 477, 480-82.

${ }^{76}$ GJ Postema, 'Jurisprudence as Practical Philosophy' (1998) 4 Legal Theory 329, 357. Similarly, in his writings on common law theory, the claims about time-boundedness seem to be grounded in features of the common law, not all law. See, eg, Postema, 'Classical Common Law (Part II)' (n 64) 21-23.
} 
have embraced the view that the normativity of law is necessarily historical. For example, he has written about '[l]aw's essential temporality ... [which] lies in the very nature of law and its distinctive mode of normativity'. ${ }^{77}$ Postema has also written about the 'essentially historical' nature of law. ${ }^{78}$ It is thus unclear whether Postema thinks that the time-constrained idea of normativity is unique to common law theory, or that this is an idea true of all law even if only common law theory made it explicit.

I want to propose here yet another way of understanding the relationship between natural law theory, legal positivism and common law theory. This view sees these as three models of law. ${ }^{79}$ Common law theory is thus one of (at least) three possible accounts of law's normativity, with law in different times and places coming closer to one of the three. On this view, we can distinguish between three pure forms of the authority of law: reason-based, will-based, and time-based. These correspond, roughly, to natural law theory, legal positivism and common law theory.

Real-world instantiations of law rarely if ever exhibit pure cases of these different approaches. Even within a single legal system, some areas may be closer to one type than to another; even within a single legal system some participants will push its law in one direction, others in another. Nevertheless, and despite the fact that ideas travel (which is why all actual legal systems are the product of different and occasionally conflicting influences), arguably there will remain differences among legal systems in how close they are to each of the different pure conceptions. We may think of a 'common law jurisdiction' as a legal system closer to pure time-based authority, which means there are going to be systemic differences between such a legal system and another that is closer to one of the other conceptions. At the same time, the model view acknowledges that labels are always simplifications, and that common law legal systems are complex and diverse. For instance, even in common law jurisdictions, much of the law today is the product of statutes, and statutes are harder to fit within a timebound conception of law's authority. ${ }^{80}$ On the other hand, even the common law element in common law jurisdictions may be subject to interpretation and reconceptualisation in terms of the other theories of law's authority. ${ }^{81}$

These last points help bring in an additional timed aspect into our analysis. To understand it, I borrow the idea of convergent evolution from biological evolutionary theory. In essence, it stands for the possibility that organs

${ }^{77}$ See GJ Postema, 'Melody and Law's Mindfulness of Time' (2004) 17 Ratio Juris 203, 207, 219-25 (quotation at 219).

${ }^{78}$ GJ Postema, 'On the Moral Presence of Our Past' (1991) 36 McGill Law Journal 1153, 1156-57.

${ }^{79}$ On the idea underlying this sentence, see D Priel, 'Are Jurisprudential Debates Conceptual? Some Lessons from Democratic Theory' (2012) 50 Osgoode Hall Law Journal 359, 398-401. It is further elaborated in D Priel, 'Jurisprudential Theories as Models' (unpublished manuscript).

${ }^{80}$ See Luban (n 75) 1047-50.

${ }^{81}$ See generally D Priel, 'Conceptions of Authority and the Anglo-American Common Law Divide’ (2017) 65 American Journal of Comparative Law 609. 


\section{Dan Priel}

performing similar functions will evolve in different species completely independently. This happens when different species are exposed to similar evolutionary pressures. A well-known example is the eye, which evidence strongly suggests evolved independently several times. Notably, even though different organs of vision perform roughly the same function, they are structured differently and they perform their function somewhat differently.

Similarly, in the context of law, it is possible that institutions we now collectively call 'law' have emerged independently in different societies. The social pressures that led to the emergence of legal structures may have been similar (a society of growing size and complexity, division of social roles and labour), but different background conditions (in existing cultural norms, physical environment, technological development) may have led to the emergence of different bases for legal authority, and consequently to different legal forms that fit those ideas. As a result, something that may count as law under one type of authority may not under another. Unlike the biological case, however, it is easy to conceive of different conceptions of authority existing within a single legal system.

It is a mix of historical ignorance and the philosophical fetish for the unified explanation that explains varied phenomena in terms of one single structure ('all law is necessarily X', where $\mathrm{X}$ is a set of structural features) that blinded philosophers to this possibility. What is true, though, is that with time, partly because ideas travel, partly because of convergence in the environmental conditions, partly because even within a single legal system not everyone thinks alike, different ideas of authority got blended together, such that modern legal systems typically exhibit conflicting ideas of authority. Surprisingly, this may have helped make claims to universality seem more plausible, because anyone who sought to explain law's authority in terms of one of three possibilities could find something in any legal system they considered to support their views. However, this is where a historical understanding - one that shows the origins of ideas and their evolution - can explain why ignoring the different conceptions of authority that co-exist within a single legal system, leads to error.

The suggestion made in the last paragraph is, as presented, rather speculative. It clearly requires a lot more than I can do here to substantiate it, but if it is along the right lines then we can make sense of some legal systems' being closer to, say, reason-based ideas of authority (a legal system grounded more in, and thus closer to, natural law theory) while there are others where time-based ideas of authority are more prominent (a legal system closer to common law theory). This approach may explain how different legal systems emerge and evolve in response to particular social pressures, why different theories of law's authority may gain prominence in different places or in different times, and how a legal system that may begin closer to a particular conception of law's authority will drift towards another. It can also makes sense of the fact - very much confirmed by reality - that different legal systems do not just differ in their geographical scope and in the content of their rules; they sometimes differ also in their underlying idea of law. It is this fact that explains why conversation between people 
in different legal systems is sometimes difficult, and why this difficulty extends to legal theorists. ${ }^{82}$

An important possible implication of this view is that the very idea of law may not be politically neutral. For if there are indeed different conceptions of law's authority, and if those different conceptions are plausibly associated with different political ideologies, and those correspond to somewhat different legal practices, then a legal system more aligned with a particular conception of authority may have a different political hue from law instantiated closer to another conception. It is not a coincidence, I think, that those who have emphasised the time-based conception of law's authority have often found the political ideas of Burke and Oakeshott congenial to their account of law. It is also not a coincidence that this brand of conservatism is quite different from the conservatism associated with some versions of reason-based natural law theory.

\section{Jurisprudence with Humans}

The previous subsection presents a view that could be seen to be in conflict with Postema's. I have argued for (at least) three different possible paths to law's authority, only one of which is time-based; at least in some places, Postema argued that all law's authority is embedded in time. As he put it:

Time is essential to law's distinctive normativity. Law is capable of offering effective normative guidance to rational self-directing and socially interacting agents only if it is sufficiently congruent with their social lives and the activities and practices that structure them through time. ${ }^{83}$

There are two possible ways of mitigating this apparent disagreement. The first is that while I may have provided a 'sociological' account of people's beliefs about law's authority, Postema's account is philosophical in that it focuses on what actually grounds law's authority. The difference is that to show that my view is incorrect takes empirical evidence that will indicate the three different views do not actually exist; to show that Postema's view is incorrect calls for a refutation of a 'philosophical' argument. I will explain below why I reject this attempt of reconciling the two views and the sharp distinction that underlies it. A second response is quite different, and I believe more promising: it asserts that while in theory the three conceptions of law's authority are conceivable, in reality, because of the way humans are, law's authority will always be (albeit to varying degrees) dependent on time.

\footnotetext{
${ }^{82}$ See D Priel, 'Is There One Right Answer to the Question of the Nature of Law?' in W Waluchow and S Sciaraffa (eds), Philosophical Foundations of the Nature of Law (Oxford University Press 2013) 322, 339-40.

${ }^{83}$ Postema (n 77) 225.
} 
Let me begin with the first suggestion. This response is likely to be the more popular one among legal philosophers, reflecting the assumption that a 'theory' of authority (just like a theory of law) should explain all law in one way. This answer strikes me as misguided. In somewhat different formulations I have dealt with it elsewhere, so I will keep my remarks here brief. This view rests on the unstated assumption in much jurisprudential writing that there is one successful account of law's authority. This view also effectively ignores the idea that law is a social construction that humans are free to design as they will. This view assumes that the category law (unlike its content) is not a matter of social construction (and as such something whose boundaries are to be learned by empirical inquiry) but a philosophical question to be determined by conceptual analysis. ${ }^{84}$

This argument thus depends on a distinction between attitudes about the practice, and attitudes within the practice. The latter are the attitudes of those who participate in the practice, while the former are those of the theorists who investigate the practice. In reality, the boundaries between the two types are often blurred. As practices mature they tend to generate self-referential attitudes, and those often influence the practice itself in terms of what it takes to engage in the practice successfully, what makes it worthwhile, what makes it legitimate. Someone who 'erroneously' believes that unjust law is not law (or, if it is any different, that unjust law lacks authority) may practise law differently from someone who rejects this view. Her attitudes about the practice will not be easily separated from how she acts within the practice. If certain views about the 'philosophical' question become dominant, they will change the practice itself. Interestingly, such an influence of attitudes about the practice on the practice itself will sometimes happen even when a scholar seeks to provide an 'external', conceptual account of the practice, one meant to leave the practice as it is. For if a scholar's work is read and influences practitioners, it may affect their understanding of their own practice. ${ }^{85}$ Unlike fire, earthquakes or diseases, where we can plausibly say that people in the past were mistaken about them, in the case of law, what people thought about the practice is relevant for understanding the practice itself. ${ }^{86}$

\footnotetext{
${ }^{84}$ If the category itself is a social construction, why should its features and boundaries not be studied like any other social construction, ie empirically? See D Priel, 'Law as a Social Construction and Conceptual Legal Theory' (2019) 38 Law and Philosophy 267.

${ }^{85}$ For one example, consider the adoption, incorporation, and adaptation of Hans Kelsen's ideas in court decisions discussing the legal implications of a revolution. For a survey and discussion of such cases, see T Mahmud, 'Jurisprudence of Successful Treason: Coup d'Etat \& Common Law' (1994) 27 Cornell International Law Journal 49. Kelsen (along with others) suggested that this may be a mistaken application of his own views (see ibid 110-13), but it is still the case that 'theoretical' ideas purportedly about the practice have become part of the practice.

${ }^{86}$ Even in the case of natural kinds, matters are more complicated. Consider: would the category of fish be a matter on which we can declare people in the past to have been wrong? Sometimes, but not always. cf J Dupré, 'Natural Kinds and Biological Taxa' (1981) 90 Philosophical Review 66.
} 
The alternative proposed here treats different conceptions of authority as models. It adds to it the idea that even if one can conceive of a purely reasonbased conception of authority, real-world specimens of law will not be able to rid themselves of their relation to time, because humans are time-constrained creatures. ${ }^{87}$ If this is indeed the case, this may be enough to vindicate Postema's idea that all possible human law is to going to be related to time.

But why should we think that humans are creatures that necessarily live in time, and 'with' time? Anthony Kronman presented a very strong version of this view, one that he thought posed 'a challenge to the philosophy of law'. The challenge was to explain the fact that ' $[\mathrm{r}]$ espect for past decisions ... is a feature of law in general', something he said 'has no place in philosophy is indeed antithetical to its governing spirit'. ${ }^{88}$ The past had this essential role for the law, because in law (but not in philosophy) 'the past is ... a repository ... of value, with the power to confer legitimacy on actions in the present'. ${ }^{89}$ While Postema shares with Kronman the central role he gave to the past in understanding law, and even more the notion of time as the basis for a normative theory for law, he did not accept these rather extravagant claims. ${ }^{90}$ The past is not binding upon us for its own sake. Contrary to Kronman's claims that seem to assume that morality is in the domain of timeless ideas, Postema's view is that our entire practical lives (even beyond the law) are deeply embedded in time. Our practical commitments are 'communal' or 'interpersonal' to their core. ${ }^{91}$ And since political communities exist over generations, they have a historical dimension. In Postema's view, the basis for law's time-boundedness is that morality, and specifically justice, is time constrained. Law's embeddedness with time is because it plays a role in the communal discourse that is constitutive of morality. ${ }^{92}$

I am sympathetic to this picture, but wish to explain it in a somewhat different way. Where Postema focuses on features of practical reason, I prefer to look to human nature. That makes my approach more overtly naturalistic. It takes

\footnotetext{
${ }^{87}$ Some have argued that limiting jurisprudence to humans unduly restricts its scope. They have urged us to think about jurisprudence general enough to capture law in alien society. See, eg, Shapiro (n 21) 406-07, note 16. This is an ill-conceived and self-defeating idea. See D Priel, 'Jurisprudence and Necessity' (2007) 20 Canadian Journal of Law and Jurisprudence 173, 188-89; Priel (n 17) 23, fn 41.

${ }^{88}$ Kronman (n 7) 1032.

89 ibid 1033.

${ }^{90}$ Postema (n 78) 1164.

${ }^{91}$ GJ Postema, 'Public Practical Reason: Political Practice' (1995) 37 Nomos 345, 357-60, passim; GJ Postema, 'Integrity: Justice in Workclothes' (1997) 82 Iowa Law Review 821, 840-43, 848-51. A related view is found in M Krygier, 'Law as Tradition' (1986) 5 Law and Philosophy 237, 245 ('the past of law, as of every tradition, is not simply part of its history; it is an authoritative significant part of its present'). Krygier insists that law 'must be' understood as a traditional social practice, and that this means that the " "time-free" staples of modern jurisprudence are not enough': ibid 239.

${ }^{92}$ Postema, 'Integrity' (n 91) 854-55; Postema (n 77) 220-21. This is also the essence of Dworkin's view of law and morality.
} 
both morality and law to be human practices, and as such to be human shaped: they are built on foundations of human nature (humans' natural needs, preferences and dispositions), and have been further reshaped by human thought, discourse and action throughout history, as well as the circumstances (social, political, technological) in which they find themselves. ${ }^{93}$ To the extent that Postema is correct about the nature of practical reason, it is so, I argue, because of what humans and their living conditions are like. Humans are creatures whose practical lives exist in time, and so are their morality and laws. Thus, even if one can conceive of a purely reason-based (legal) authority, humans may not be able to sustain such a legal system in practice. If there is any necessity here, it is a natural necessity drawn from facts about human nature, not any kind of conceptual necessity.

Perhaps the most basic element of humanity that gives time its normative significance is memory. That memory is crucial for humanity has been the subject of works of art, as well as of psychological case studies of people who lost their memory. Most obviously, without memory, humans lose their ability to form life plans and sustain meaningful relationships; without memory, learning becomes impossible. There is also the fact that humans feel a connection to their ancestors, and see themselves as part of an unbroken historical group (family, clan, tribe, nation) that began before them and will persist after them.

Memory is also significant for some of the most rudimentary aspects of normative thought. To the extent that a legal action is a reaction to a person's past behaviour, it requires memory. Thus, the idea of holding people to account is not possible without memory. Longer-term memory is necessary for one of the most undemanding notion of fairness - treating present actions in the same way we treated similar actions in the past. It is true that human normative thought does not always take this form. In theory, one could always pass judgment 'on the merits' of every case, without regard to past judgments on similar actions. Such a possibility might even suggest that relying on past decisions makes no sense: if we decided wrongly in the past, there is little point in repeating the error; and if we decided correctly, then doing the same now can be justified by appeal to the reasons behind that decision, not to the earlier decision itself. But in reality constraints of time, fairness considerations, and even doubts about the possibility of finding the 'correct' answer may warrant sticking with an earlier decision. These considerations are powerful enough that even in legal systems that do not recognise precedent as a source of law, courts tend to follow past decisions. They also explain why attempts in some legal systems to prohibit the use of precedent have all eventually been abandoned.

\footnotetext{
${ }^{93}$ For accounts broadly in line with this view, see P Kitcher, The Ethical Project (Harvard University Press 2011); K Sterelny, The Evolved Apprentice: How Evolution Made Humans Unique (MIT Press 2012) ch 7.
} 
In addition to the psychological pull of norms of fairness ('treating like cases alike'), the past also has a 'sociological' impact on the law, as past normative choices may be constrained by present institutional possibilities. A legal system, unlike a book on moral philosophy, has institutional mechanisms that change in response to past decisions. Enforcement mechanisms, institutionalised knowledge-dissemination devices (courses, books), contracts and other legal documents - all are shaped on the basis of past normative choices, and help enshrine them. They often make maintaining past decisions simpler and cheaper, rather than changing course. ${ }^{94}$

The time-based conception of authority may be thought to derive from these facts and give them normative primacy. Time-based authority in its idealised form does not assume that there is a moral truth out there that law aims to match. Rather, it treats its own past as constructive of the relevant legal truth. This is relevant in an underappreciated way to familiar jurisprudence debates: since past decisions change the environment in which present decisions are made, it follows that what constitutes 'the right answer purely on the merits of the case' may be different depending on existing institutional context, which (as explained) is dependent on the past.

The effect of this may be significant: the views described in the previous paragraph are close to those held by Dworkin, and as such are relevant to familiar questions about the relationship between law and morality. They are also relevant when trying to make sense of the way different legal systems differ from each other, and why they have a certain shape and not another. If I am right in my overall view about authority, we can explain some of the substantive differences among legal systems as derived from their historical ties to different conceptions of authority. ${ }^{95}$

All this is significant for the question of the inevitability of some time-based element in an account of law's authority, because it shows how the past may have normative impact even when decision makers do not make any conscious effort to align present decisions with past ones. Can time nevertheless be avoided in the

\footnotetext{
94 'Path dependence' is a general term that has been used for different processes. Some of them are more closely related to the 'psychological' impact of time. For instance, 'mental models' influence the way people interpret the world. See AT Denzau and DC North, 'Shared Mental Models: Ideologies and Institutions' (1994) 47 Kyklos 3. This idea is close to what lawyers call 'reasonable expectations'. In the text I talk about the costs of initial institutional choices and subsequent changing course. But the two processes are related, because some of the costs may be in changing (psychological) expectations generated by past institutional choices. All this ties to the work (of Postema and Dworkin, among others) on integrity as a moral ideal of communities, which may be read as broadly in agreement with these ideas. Even if one does not accept these ideas as an account of morality, they make sense in the context of thinking about law. For law is a public institution, whose judgments need to be accepted by those subject to it. It thus has to be mapped against understandings and expectations (the 'mental models') of people. This creates a connection, perhaps surprising, between works that are not overly naturalistic (or even hostile to it) and more empirically-grounded works on morality such as the sources cited in $\mathrm{n} 93$.

${ }^{95}$ For some examples, see Priel (n 81) 645-52.
} 
law, despite all this? In certain domains humans have developed practices that are relatively impervious to time-bound thinking. Perhaps the most notable example is scientific practice. Even where the science in question has a time element built into it (as is the case with evolutionary theory), scientific ethos tends to give little authority to the discipline's own past. Admittedly, even here the picture is more complex (scientists are human too), but there is no denying that precedent and tradition have no authority in science in the way they do in the law.

Against this background, we may understand those who argue for law in terms of reason-based ('natural law') or will-based ('positivist') conceptions of authority do not present 'descriptive' or 'conceptual' claims about the nature of law. Rather, their efforts should be understood as idealisations of law based on the model of science, and an attempt to create law whose authority is similarly independent of appeal to the past.

The popularity of the progressive-science model of jurisprudence shows that this ethos has proven attractive in the philosophy of law, so much so that its proponents have put it forward not just at the level of jurisprudential method, but as a foundation for a substantive theory of law as well. But despite centuries of effort, attempts to model human law on science have not proven successful. Perhaps with the advent of legal automation such ideas might finally be more successful. Until this (maybe) happens, it remains an interesting historical and theoretical question why science and law have proven so different on this score. (Here, as elsewhere, law is more like engineering than science, and engineering has a more profound relationship with time.) Until then, a theory of law that aims at descriptive accuracy has to acknowledge the normative role time plays in the law. In saying all this, I have ended up accepting something like Postema's claim about the inevitable connection between law's authority and time.

\section{CONCLUSION}

In most jurisprudential thinking time does not play a significant role. This is most evident in the characterisation of the domain as concerned with necessary and, as such, timeless truths. This view, as I suggested at the outset, seems to be based on the assumption that if there are no such timeless truths then there is no room for a philosophy of law, only sociology (broadly conceived): contingent, local, empirical. ${ }^{96}$ As I have tried to show, much of contemporary jurisprudence is time-less in other senses as well: uninterested in the history of law, the history of jurisprudence, or the role of time in law. The primary aim of this chapter has

\footnotetext{
${ }^{96}$ This is the worry that motivates Raz's question (n 24) 17, '[C]an there be a theory of law?' As he defines it, a theory of law is limited to necessary and important truths about law. If there are no necessary truths, then on this view there cannot be a theory (philosophy) of law. One aim of a model-based approach to jurisprudence suggested here (and defended in Priel ( $\mathrm{n} 79)$ ) is to explain why this assumption is not warranted.
} 
been to bring time back in in three different ways. The first and least controversial sense is that jurisprudence, like any learned activity, has a history. This will not be denied by anyone, but it will be deemed insignificant to the subject matter itself as a kind of progressive science with accumulated knowledge. Against this view, I have argued that it is difficult to draw a clear line between legal practice and legal theory, because the latter typically emerges from a more-or-less selfconscious attempt by practitioners to understand their practice. And thus, to the extent that law is tied to time in a more significant sense, so is jurisprudence.

At a second level, jurisprudence is tied to time because law, or at least the kind of law called 'common law', is steeped in time in the sense that the very justification for saying that something is the law now is because it was judged to be the law in the past. The practice of appealing to precedent is one that uses the law's own past as a form of justification. But though familiar to lawyers, to say 'this is what we should do now, because we did something similar in the past' is not an obvious statement. Despite the centrality of this kind of reasoning in the common law, it is a feature of law that many jurisprudential theories have neglected.

Finally, at the most philosophical level, there is the fact that jurisprudence is a study of a human practice. Here, I drew on history, both by turning to the philosophy of history and by examining the way that human institutions exist in time. I took Postema's invitation to think of jurisprudence as practical reason as an invitation to think of it in terms of the way humans reason. ${ }^{97}$ And it is here that we should look at the way psychologists have improved our understanding of human reasoning. I took ideas that were not developed within a naturalistic framework and have attempted to 'naturalise' them.

It is a testament to the breadth and depth of Postema's body of work that he has made significant contributions to all three levels: to the philosophical study of past jurisprudential thought, to the articulation of common law theory as a distinct theory of law, and to the temporal element in law as an inescapable part of a study of the role of law in practical reasoning.

${ }^{97}$ cf D Priel, 'Action, Politics, and the Normativity of Law' (2017) 8 Jurisprudence 118, 121-22. 